\title{
Ameliorative Effect of Vanillin against Propiconazole Induced Hepatorenal and Testicular Injury in Male Albino Rats
}

\author{
Mahmoud M. Elalfy ${ }^{1 *}$, SaraT.Elazab ${ }^{2}$, Mohamed F. Hamed ${ }^{3}$, and Mona G. Elhadidy ${ }^{4}$ \\ ${ }^{1}$ forensic medicine and toxicology, faculty of veterinary medicine, Mansoura university, Egypt \\ ${ }^{2}$ pharmacology department, faculty of veterinary medicine, Mansoura university, Egypt \\ ${ }^{3}$ pathology department, faculty of veterinary medicine, Mansoura university, Egypt \\ ${ }^{4}$ Medical physiology, Faculty of medicine, Mansoura university, Egypt
}

*Corresponding Author: Mahmoud M. Elalfy, forensic medicine and toxicology, faculty of veterinary medicine, Mansoura University, Egypt.

\begin{abstract}
Vanillin commonly used in pharmaceutical industry, food and beverage processing, and in cosmetics and perfumes preparation. To better understand the effects of vanillin in reduction of tissue injuries resulted from Fungicides misuses. Fungicides like propiconazole are used extensively in greenhouse nowadays. The hazard effects of mycotoxin occurrence affect all defense and immunocytes of animals and reduced its production. But safety of use of fungicide and develop of new generation of fungicide often take a focus from researchers and authority. Propiconazole treatments at different doses have no effect on body weight. Notably, vanillin treatment reduced toxic effects of propiconazole induced in male rats' evidence by liver and kidney biomarkers and improvement level of antioxidants level. Also, vanillin restored tissue architecture nearly similar to control group. Taken collectively, vanillin had a protective role against propiconazole induced toxicity.
\end{abstract}

\section{INTRODUCTION}

Conazoles, a group of fungicides, are extensively utilized in pharmaceutical and agricultural fields. They serve as agrichemicals to preserve variety of cereal crops, vegetables, and fruits. While, in therapeutics, they are applied locally or systemically to control mycotic and yeast infections (1-3). Conazoles comprise both triazole- and imidazole-antifungal agents (4).

Despite Propiconazole valuable effect in combating fungal infections, the irrational usage of PCZ may account for potential deleterious effects in mammals (5). It elicits its effect by hindering the ergosterol biosynthesis in fungi through suppressing a cytochrome P450, lanosterol-14 $\alpha$-demethylase, and subsequently lead to impairment in the synthesis of cell wall (3) Prior studies have declared that PCZ caused multiple adverse effects, as hepatotoxicity in rats and mice (6), neurotoxicity (7) and reproductive toxicity via endocrine disturbing effect (8). The researcher revealed that the toxic effect of PCZ on multiple organs may be owed to enhancement production of reactive oxygen species causing oxidative damage of biological membranes ( 9 , 10). Hence, using exogenous antioxidants may mitigate PCZ-induced toxicity in various organs.

Vanillin (4-hydroxy-3-methoxybenzaldehyde), the main component of vanilla, was extracted from several essential plant oils, particularly Vanilla pompon, Vanilla tahitensis, and Vanilla planifolia (11). Vanillin commonly used in pharmaceutical industry, food and beverage processing, and in cosmetics and perfumes preparation (12). Several pharmacological effects were recorded of vanillin as antiinflammatory, anti-carcinogenic (13) antioxidant (14), a hepatoprotective (15) and a nephroprotective (16).

The aim this study to investigate the mitigative effect of vanillin against PCZ induced hepatorenal and testicular injury in male albino rats. 


\section{Materials AND Methods}

\subsection{Tested Chemical}

propiconazole was obtain from institute for pesticide residues analysis in Doky, ministry of agriculture, Egypt. Vanillin was purchase from sigma Cairo, Egypt

\subsection{Laboratory Animals}

40 Mature males' albino rats were obtained from Experimental Unit in the Faculty of Pharmacy, Mansoura University; Animals were weighing about $100 \pm 10$ gm and obviously healthy then were grouping and housing in plastic cages with soft wood shavings as a bedding material that change adequately to ensures a low level of ammonia and to keep animals clean and dry.

Animals kept for 2 weeks for accommodation and maintained on a balanced ration before the start of the experiment. Also, standard laboratory pelleted diet and water WERE received ad libitium throughout the experiment and Light cycles of 12 hours' light to 12 hours dark seem to be adequate in order to promote rodents' breeding.

\subsection{Experimental Design for Toxicity Propiconazole and the Effects of Vanillin Curing Propiconazole Induced Injuries in Male Albino Rats}

Forty males were separated into five groups with eight rats per group. The first group was received $0.5 \mathrm{ml}$ distilled water and used as control; the second group was administered $150 \mathrm{mg} / \mathrm{kg}(6)$, 1/10 LD50), of propiconazole, the third group was gavaged $75 \mathrm{mg} / \mathrm{kg}$ (6), 1/20 LD50, of propiconazole, the fourth group was treated with 1/10 LD50 of propiconazole and was give 150 $\mathrm{mg} / \mathrm{kg}$ of vanillin intraperitoneally, the fifth group was treated with $1 / 20$ of propiconazole and was give $150 \mathrm{mg} / \mathrm{kg}$ of vanillin intraperitoneally. Both fungicide and vanillin were received twice per week for 6 weeks. The protocol was approved by Institutional Research Board of faculty of medicine, Mansoura university, Egypt (R.20.07.924) and study was done with agreement with ethical guidelines and the rest of sacrificed rats was discarded safety.

\subsection{Clinical Signs}

The animals were noticed daily throughout the experimental period for any abnormal behavior, findings, or alteration.

\subsection{Samples Collection}

ARC Journal of Animal and Veterinary Sciences
At end of treatment, rats were euthanized with overdose of thiopental $\mathrm{Na}(40 \mathrm{mg} / \mathrm{Kg}$ i.p). whole blood was collected in gel tube (not contain anticoagulant) then keep for overnight in refrigerator followed by serum separation in centrifuge at $3000 \mathrm{rpm}$ for 15 minutes then was store at $-20^{\circ} \mathrm{C}$ in Eppendorf tubes. Liver, kidney, and testicle tissues were removed and wash with saline solution and preserve in $10 \%$ buffered formalin and another one gram of each homogenized tissue was preserve in falcon tube with $1 \mathrm{ml}$ ice cold phosphate puffer (PBS). PH7.4 at -20 deep freezing.

\subsection{Biochemical Analysis}

\section{a. biochemical assays}

Sera of all rats of all groups was test for AST activity, ALT activity, urea and creatinine levels.

\section{b. Antioxidant and oxidative stress biochemical analysis}

Liver, kidney and testicular tissue homogenates were analyzed for GSH, GST, CAT, SOD1 and MDA levels by using specific kits.

\subsection{Histopathologic Examinations}

Specimens from liver, kidney and testicular tissue were fix in $10 \%$ formalin and $5 \mu$ thickness sections of specimens prepared then stained with hematoxylin and eosin (H\&E) and examined microscopically.

\subsection{Statistical Analysis}

Data was analyzed statically for variance by oneway ANOVA and least standard difference LSD, homogeneity and sample size by using SPSS program version 20. $\mathrm{P}$ value $\leq 0.05$ was consider significant (17).

\section{Results}

PLZ is used as a fungicide in agriculture especially in greenhouse. PLZ reported to induce different organ toxicity in animal models and also in human intoxication. In the current study PLZ not resulted in change in body weight or organ to body weight ratio.

In table 1, PLZ increased significantly liver enzymes, blood urea nitrogen and creatinine. While vanillin retained liver and kidney biomarkers when compared to control group. Additionally, vanillin hadn't induced any alteration in activity of liver markers or kidney parameters levels. 
Ameliorative Effect of Vanillin against Propiconazole Induced Hepatorenal and Testicular Injury in Male Albino Rats

Table1. Biochemical effects of treated groups by PLZ and or vanillin

\begin{tabular}{|l|l|l|l|l|}
\hline & ALT & GGT & Urea & creatinine \\
\hline G1 & $35.2 \pm 1.2$ & $24.3 \pm 0.9$ & $47.3 \pm 1.6$ & $0.6 \pm 0.2$ \\
\hline G2 & $35.4 \pm 1.02$ & $24.6 \pm 0.91$ & $47.8 \pm 1.06$ & $0.66 \pm 0.02$ \\
\hline G3 & $60.74^{\mathrm{a}} \pm 2.03$ & $53.97^{\mathrm{a}} \pm 2.02$ & $77.62^{\mathrm{a}} \pm 2.1$ & $1.82^{\mathrm{a}} \pm 0.06$ \\
\hline G4 & $44.43^{\mathrm{b}} \pm 2.07$ & $33.34 \pm 1.14$ & $59.02 \pm 1.55$ & $0.86 \pm 0.44$ \\
\hline G5 & $36.2 \pm 1.22$ & $25.3 \pm 0.9$ & $48.3 \pm 1.76$ & $0.66 \pm 00.02$ \\
\hline G6 & $35.12 \pm 1.02$ & $24.43 \pm 0.93$ & $47.53 \pm 1.66$ & $0.67 \pm 0.021$ \\
\hline
\end{tabular}

a, $b$ significant at $p$ value $\leq 0.05$

In table 2, 3, and 4 PLZ reduced level of antioxidant like GSH, GST, SOD1 and catalase in liver, kidney and testicular tissue. Also, PLZ increased lipid peroxidation evident by level of MDA when compared to control group. Notably, vanillin restored level of antioxidant levels of

Table2. Antioxidant/ Oxidant level in liver tissue homogenates in treated groups versus control one

\begin{tabular}{|l|l|l|l|l|l|}
\hline & $\begin{array}{l}\text { GSH } \\
\text { mg/g. tissue }\end{array}$ & $\begin{array}{l}\text { GST } \\
\text { U/g. tissue }\end{array}$ & $\begin{array}{l}\text { SOD } \\
\text { U/g. tissue }\end{array}$ & $\begin{array}{l}\text { CAT } \\
\text { U/g. tissue }\end{array}$ & $\begin{array}{l}\text { MDA } \\
\text { nmol/g. tissue }\end{array}$ \\
\hline g1 & $28.69 \pm 0.19^{\mathrm{a}}$ & $10.78 \pm 0.181^{\mathrm{a}}$ & $27.42 \pm 1.04^{\mathrm{a}}$ & $17.96 \pm 0.194^{\mathrm{a}}$ & $30.97 \pm 0.193^{\mathrm{c}}$ \\
\hline $\mathbf{g} 2$ & $28.69 \pm 0.295^{\mathrm{a}}$ & $10.78 \pm 0.281^{\mathrm{a}}$ & $27.42 \pm 1.24^{\mathrm{a}}$ & $17.96 \pm 0.24^{\mathrm{a}}$ & $30.97 \pm 0.23^{\mathrm{c}}$ \\
\hline $\mathbf{g 3}$ & $15.91 \pm 1.342^{\mathrm{b}}$ & $6.05 \pm 0.37^{\mathrm{c}}$ & $16.08 \pm 1.33^{\mathrm{b}}$ & $10.94 \pm 0.31^{\mathrm{c}}$ & $73.96 \pm 1.39^{\mathrm{a}}$ \\
\hline $\mathbf{g 4}$ & $19.17 \pm 1.9^{\mathrm{b}}$ & $7.69 \pm 0.54^{\mathrm{b}}$ & $24.82 \pm 1.49^{\mathrm{a}}$ & $13.54 \pm 0.36^{\mathrm{b}}$ & $61.14 \pm 2.12^{\mathrm{b}}$ \\
\hline $\mathbf{g 5}$ & $28.16 \pm 0.92^{\mathrm{a}}$ & $10.78 \pm 0.28^{\mathrm{a}}$ & $27.42 \pm 1.24^{\mathrm{a}}$ & $17.96 \pm 0.39^{\mathrm{a}}$ & $30.17 \pm 0.39^{\mathrm{c}}$ \\
\hline $\mathbf{g 6}$ & $28.69 \pm 0.15^{\mathrm{a}}$ & $10.78 \pm 0.21^{\mathrm{a}}$ & $27.42 \pm 1.4^{\mathrm{a}}$ & $17.96 \pm 0.24^{\mathrm{a}}$ & $30.17 \pm 0.43^{\mathrm{c}}$ \\
\hline
\end{tabular}

$\mathrm{a}, \mathrm{b}, \mathrm{c}$ significant at $\mathrm{p}$ value $\leq 0.05$

Table3. Antioxidant/ Oxidant level in kidney tissue homogenates in treated groups versus control one

\begin{tabular}{|l|l|l|l|l|l|}
\hline & $\begin{array}{l}\text { GSH } \\
\text { mg/g. tissue }\end{array}$ & $\begin{array}{l}\text { GST } \\
\text { U/g. tissue }\end{array}$ & $\begin{array}{l}\text { SOD } \\
\text { U/g. tissue }\end{array}$ & $\begin{array}{l}\text { CAT } \\
\text { U/g. tissue }\end{array}$ & $\begin{array}{l}\text { MDA } \\
\text { nmol/g. tissue }\end{array}$ \\
\hline g1 & $21.69 \pm 0.25^{\mathrm{a}}$ & $11.72 \pm 0.71^{\mathrm{a}}$ & $26.42 \pm 1.4^{\mathrm{a}}$ & $15.96 \pm 0.74^{\mathrm{a}}$ & $26.97 \pm 0.43^{\mathrm{c}}$ \\
\hline g2 & $28.69 \pm 0.15^{\mathrm{a}}$ & $10.8 \pm 0.1^{\mathrm{a}}$ & $27.2 \pm 1.24^{\mathrm{a}}$ & $17.6 \pm 0.44^{\mathrm{a}}$ & $30.97 \pm 0.73^{\mathrm{c}}$ \\
\hline g3 & $14.91 \pm 1.2^{\mathrm{b}}$ & $7.05 \pm 0.7^{\mathrm{c}}$ & $15.08 \pm 1.53^{\mathrm{b}}$ & $12.4 \pm 0.71^{\mathrm{c}}$ & $83.96 \pm 1.60^{\mathrm{a}}$ \\
\hline g4 & $19.67 \pm 1.19^{\mathrm{b}}$ & $7.69 \pm 0.34^{\mathrm{b}}$ & $24.82 \pm 1.39^{\mathrm{a}}$ & $11.4 \pm 0.16^{\mathrm{b}}$ & $71.14 \pm 2.12^{\mathrm{b}}$ \\
\hline g5 & $20.69 \pm 0.35^{\mathrm{a}}$ & $19.78 \pm 0.51^{\mathrm{a}}$ & $2342 \pm 1.14^{\mathrm{a}}$ & $15.6 \pm 0.44^{\mathrm{a}}$ & $28.97 \pm 0.43^{\mathrm{c}}$ \\
\hline g6 & $20.9 \pm 0.25^{\mathrm{a}}$ & $11.78 \pm 0.21^{\mathrm{a}}$ & $25.42 \pm 1.4^{\mathrm{a}}$ & $15.6 \pm 0.24^{\mathrm{a}}$ & $26.97 \pm 0.43^{\mathrm{c}}$ \\
\hline
\end{tabular}

$a, b, c$ significant at $p$ value $\leq 0.05$

Table4. Antioxidant/ Oxidant level in testicle tissue homogenates in treated groups versus control one

\begin{tabular}{|l|l|l|l|l|l|}
\hline & $\begin{array}{l}\text { GSH } \\
\text { mg/g. tissue }\end{array}$ & $\begin{array}{l}\text { GST } \\
\text { U/g. tissue }\end{array}$ & $\begin{array}{l}\text { SOD } \\
\text { U/g. tissue }\end{array}$ & $\begin{array}{l}\text { CAT } \\
\text { U/g. tissue }\end{array}$ & $\begin{array}{l}\text { MDA } \\
\text { nmol/g. tissue }\end{array}$ \\
\hline g1 & $20.69 \pm 0.25^{\mathrm{a}}$ & $9.78 \pm 0.1^{\mathrm{a}}$ & $25.12 \pm 1.04^{\mathrm{a}}$ & $15.6 \pm 0.34^{\mathrm{a}}$ & $29.97 \pm 1.03^{\mathrm{c}}$ \\
\hline g2 & $25.9 \pm 0.25^{\mathrm{a}}$ & $11.8 \pm 0.21^{\mathrm{a}}$ & $26.2 \pm 1.4^{\mathrm{a}}$ & $17.06 \pm 0.24^{\mathrm{a}}$ & $30.07 \pm 01.3^{\mathrm{c}}$ \\
\hline g3 & $16.1 \pm 1.2^{\mathrm{b}}$ & $5.05 \pm 0.37^{\mathrm{c}}$ & $16.78 \pm 1.3^{\mathrm{b}}$ & $11.4 \pm 0.71^{\mathrm{c}}$ & $77.96 \pm 2.1^{\mathrm{a}}$ \\
\hline g4 & $18.7 \pm 1.9^{\mathrm{b}}$ & $7.69 \pm 0.34^{\mathrm{b}}$ & $17.82 \pm 1.9^{\mathrm{a}}$ & $13.1 \pm 0.8^{\mathrm{b}}$ & $61.74 \pm 2.2^{\mathrm{b}}$ \\
\hline g5 & $20.06 \pm 0.25^{\mathrm{a}}$ & $9.8 \pm 0.41^{\mathrm{a}}$ & $24.12 \pm 1.4^{\mathrm{a}}$ & $14.96 \pm 1.01^{\mathrm{a}}$ & $28.97 \pm 0.73^{\mathrm{c}}$ \\
\hline g6 & $20.09 \pm 0.95^{\mathrm{a}}$ & $9.78 \pm 0.1^{\mathrm{a}}$ & $25.2 \pm 1.04^{\mathrm{a}}$ & $14.96 \pm 1.04^{\mathrm{a}}$ & $29.7 \pm 0.53^{\mathrm{c}}$ \\
\hline
\end{tabular}

$a, b, c$ significant at $p$ value $\leq 0.05$

In histopathological figure 1, 2, 3, A showed normal histological structure of liver, kidney and testicular tissue (normal seminiferous tubules with complete spermatic series) in control group 1 and also in group received vanillin. PLZ treated group showed necrosis, degeneration and leucocytic infiltration in different tissue in figure
1, 2, 3 B. Notably, vanillin treatment restored injury induced by PLZ quite similar to normal tissue marketecture of normal rats. Taken collectively, from the biochemical and histological biomarkers, vanillin had a ameliorative effects against injury induced PLZ 


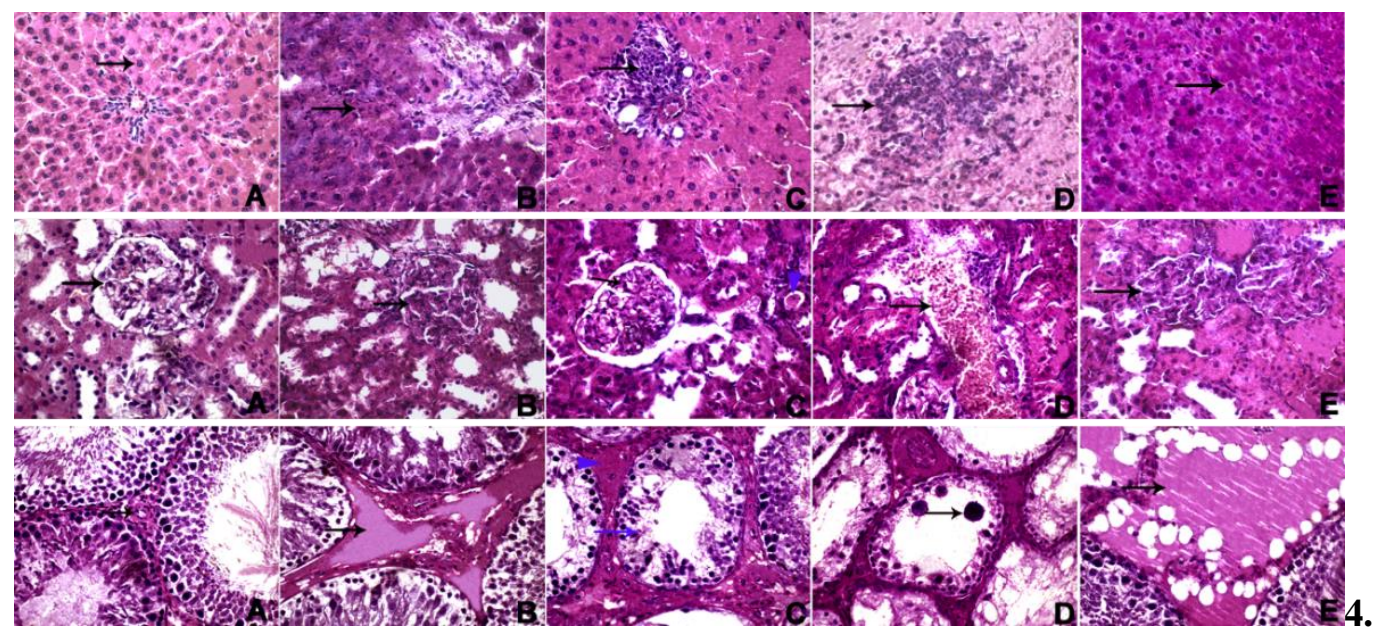

Figure1. The depicted figure shown normal liver, kidney and testicle in control group 1(A), liver necrosis, renal and seminiferous tubules degeneration in group $3,4(B, C)$, vanillin retain nearly marketecture of testicle > kidney> liver respectively in group $4,5(D, E)$.

\section{DISCUSSION}

Propiconazole $(\mathrm{PCZ})$ is a triazole fungicide had extensively used in agriculture (7). The PLZ had no effects on the body weight or relative organ weights as previously mentioned before (18). PLZ had a hepatotoxic effects $(5,19,20)$, nephrotoxic (21), induced testicular damage (18, $22,23)$, induction of oxidative stress $(7,9)$ and tumorin rats (24). Previously we found that vanillin had hepatorenal protections against gentamycin induced toxicity in male albino rats (25). In current study, vanillin improved the liver enzymes, creatinine and blood urea nitrogen of rats treated with different dose of propiconazole. Similarly, vanillin had a hepatorenal protections $(16,25)$ through increased the antioxidant levels $(14,15)$. Also, Vanillin increased regeneration in injured tissue as a common modulator $(26,27)$ and vanillin could enhanced the expression of recombinational repair genes in tissues of rats treated by azoxymethane (28). Notably, vanillin had a protective role, restoring of testicular and renal tissues (29) and had a vital role in mitigation of oxidative stress and toxicity induced by toxic agents (30). Only noticed that vanillin reported to increase the antioxidant level and maintained oxidant at basal level (31), similarly, other plant extract could increase the antioxidant than basal level. On the conclusions, vanillin could have a role in protection against injuries induced by propiconazole fungicide.

\section{ACKNOWLEDGMENTS}

We thanked Amr El-bawady from pesticide residues analysis institute, ministry of agriculture for provided us with propiconazole pesticide after HPLC analysis and ensured the concentration pesticide in the current commercial product.

\section{REFERENCES}

[1] Georgopapadakou NH, Walsh TJ. Antifungal agents: chemotherapeutic targets and immunologic strategies. Antimicrobial agents and chemotherapy. 1996;40(2):279.

[2] Sheehan DJ, Hitchcock CA, Sibley CM. Current and emerging azole antifungal agents. Clinical microbiology reviews. 1999;12(1):40-79.

[3] Zarn JA, Brüschweiler BJ, Schlatter JR. Azole fungicides affect mammalian steroidogenesis by inhibiting sterol 14 alpha-demethylase and aromatase. Environmental health perspectives. 2003;111(3):255-61.

[4] Tully DB, Bao W, Goetz AK, Blystone CR, Ren $\mathrm{H}$, Schmid JE, et al. Gene expression profiling in liver and testis of rats to characterize the toxicity of triazole fungicides. Toxicology and applied pharmacology. 2006;215(3):260-73.

[5] Chen P-J, Moore T, Nesnow S. Cytotoxic effects of propiconazole and its metabolites in mouse and human hepatoma cells and primary mouse hepatocytes. Toxicology in vitro. 2008;22(6):1476-83.

[6] Sun G, Thai S-F, Tully DB, Lambert GR, Goetz AK, Wolf DC, et al. Propiconazole-induced cytochrome P450 gene expression and enzymatic activities in rat and mouse liver. Toxicology letters. 2005;155(2):277-87.

[7] Noshy PA, Elhady MA, Khalaf AAA, Kamel MM, Hassanen EI. Ameliorative effect of carvacrol against propiconazole-induced neurobehavioral toxicity in rats. Neurotoxicology. 2018;67:141-9.

[8] Rockett JC, Narotsky MG, Thompson KE, Thillainadarajah I, Blystone CR, Goetz AK, et 
al. Effect of conazole fungicides on reproductive development in the female rat. Reproductive toxicology. 2006;22(4):647-58.

[9] Nesnow S, Grindstaff RD, Lambert G, Padgett WT, Bruno M, Ge Y, et al. Propiconazole increases reactive oxygen species levels in mouse hepatic cells in culture and in mouse liver by a cytochrome P450 enzyme mediated process. Chemico-biological interactions. 2011;194(1):79-89.

[10] Toni C, Ferreira D, Kreutz LC, Loro VL, Barcellos LJG. Assessment of oxidative stress and metabolic changes in common carp (Cyprinus carpio) acutely exposed to different concentrations of the fungicide tebuconazole. Chemosphere. 2011;83(4):579-84.

[11] Divakaran M, Babu KN, Peter K. Protocols for Biotechnological Interventions in Improvement of Vanilla (Vanilla planifolia Andrews.). Protocols for In Vitro Cultures and Secondary Metabolite Analysis of Aromatic and Medicinal Plants, Second Edition: Springer; 2016. p. 4763.

[12] Bezerra-Filho CS, Barboza JN, Souza MT, Sabry P, Ismail NS, de Sousa DP. Therapeutic potential of vanillin and its main metabolites to regulate the inflammatory response and oxidative stress. Mini Reviews in Medicinal Chemistry. 2019;19(20):1681-93.

[13] Bezerra DP, Soares AKN, de Sousa DP. Overview of the role of vanillin on redox status and cancer development. Oxidative medicine and cellular longevity. 2016;2016.

[14] Shyamala B, Naidu MM, Sulochanamma G, Srinivas P. Studies on the antioxidant activities of natural vanilla extract and its constituent compounds through in vitro models. Journal of agricultural and food chemistry. 2007;55(19):7738-43.

[15] Kamat JP, Ghosh A, Devasagayam TP. Vanillin as an antioxidant in rat liver mitochondria: inhibition of protein oxidation and lipid peroxidation induced by photosensitization. Molecular and cellular biochemistry. 2000;209(1-2):47-53.

[16] Saad HB, Driss D, Chaabouni SE, Boudawara T, Zeghal KM, Hakim A, et al. Vanillin mitigates potassium bromate-induced molecular, biochemical and histopathological changes in the kidney of adult mice. Chemico-Biological Interactions. 2016;252:102-13.

[17] Snedecor GW, Cochran WG. Statistical methods, 8thEdn. Ames: Iowa State Univ Press Iowa. 1989;54:71-82.

[18] Borai IH, Atef AA, El-Kashoury AA, Mohamed RA, Said MM. Ameliorative effects of sesame seed oil against penconazole-induced testicular toxicity and endocrine disruption in male rats. Biomed J Sci Tech Res. 2019;14(1):10365-75.
[19] Wolf DC, Allen JW, George MH, Hester SD, Sun G, Moore T, et al. Toxicity profiles in rats treated with tumorigenic and nontumorigenic triazole conazole fungicides: propiconazole, triadimefon, and myclobutanil. Toxicologic pathology. 2006;34(7):895-902.

[20] Leslie C, Reidy G, Stacey N. The effects of propiconazole on hepatic xenobiotic biotransformation in the rat. Biochemical pharmacology. 1988;37(21):4177-81.

[21] Martin MT, Brennan RJ, Hu W, Ayanoglu E, Lau C, Ren H, et al. Toxicogenomic study of triazole fungicides and perfluoroalkyl acids in rat livers predicts toxicity and categorizes chemicals based on mechanisms of toxicity. Toxicological Sciences. 2007;97(2):595-613.

[22] Costa NO, Vieira ML, Sgarioni V, Pereira MRF, Montagnini BG, Mesquita SdFP, et al. Evaluation of the reproductive toxicity of fungicide propiconazole in male rats. Toxicology. 2015;335:55-61.

[23] Aiche MA, Mallem L, Yahia E, Boulakoud MS. Toxicity of Subchronic Doses of Propiconazole, Propineb and Their Mixture on Reproductive Parameters in Male Rats. Adv Environ Biol. 2015;9(3):885-91.

[24] Ward WO, Delker DA, Hester SD, Thai S-F, Wolf DC, Allen JW, et al. Transcriptional profiles in liver from mice treated with hepatotumorigenic and nonhepatotumorigenic triazole conazole fungicides: propiconazole, triadimefon, and myclobutanil. Toxicologic pathology. 2006;34(7):863-78.

[25] Elalfy MM, Hussein YA, El-Hadidy G Mona3 and Monur Naseif. HEPATORENAL PELIOSIS A CHARACTERISTIC FEATURES OF GENTAMOX ANTIBIOTICINDUCE TOXICITY IN ALBINO RATS. International Journal of Current Innovation Research. 2018;4(2):1029-32.

[26] Elseweidy MM, Askar ME, Elswefy SE, Shawky M. Vanillin as a new modulator candidate for renal injury induced by cisplatin in experimental rats. Cytokine. 2017;99:260-5.

[27] Al-Baqami N, Hamza R. Synergistic antioxidant capacities of vanillin and chitosan nanoparticles against reactive oxygen species, hepatotoxicity, and genotoxicity induced by aging in male Wistar rats. Human \& Experimental Toxicology. 2020:0960327120943267.

[28] Ho KL, Chong PP, Yazan LS, Ismail M. Vanillin differentially affects azoxymethane-injected rat colon carcinogenesis and gene expression. Journal of medicinal food. 2012;15(12):1096102.

[29] Mohamed EAK. The protective effect of taurine and/or vanillin against renal, testicular, and hematological alterations induced by potassium 

Albino Rats

bromate toxicity in rats. The Journal of Basic and Applied Zoology. 2019;80(1):3.

[30] Kadeche L, Bourogaa E, Saoudi M, Boumendjel A, Djeffal A, El Feki A, et al. Ameliorative effects of vanillin against metribuzin-induced oxidative stress and toxicity in rats. Int J Pharm Pharm Sci. 2017;9(1):56-62.
[31] Mostafa AF, Elalfy MM, Shata A, Elhadidy MG. Prophylactic effect of aquatic extract of stevia on acetic acid induced-ulcerative colitis in male rats: a possible role of $\mathrm{Nrf} 2$ and PPAR $\gamma$. Journal of Basic and Clinical Physiology and Pharmacology. 2020;1 (ahead-of-print).

Citation: Mahmoud M. Elalfy, Sara T. Elazab, Mohamed F. Hamed, and Mona G. Elhadidy. Ameliorative Effect of Vanillin against Propiconazole Induced Hepatorenal and Testicular Injury in Male Albino Rats. ARC Journal of Animal and Veterinary Sciences. 2020; 6(2):12-17. DOI: https://doi.org/10.20431/24552518.0602002 .

Copyright: (C) 2020 Authors. This is an open-access article distributed under the terms of the Creative Commons Attribution License, which permits unrestricted use, distribution, and reproduction in any medium, provided the original author and source are credited. 